\title{
頭蓋澒椎移行部春髄腹側腫痬に対する後外側経筋間アプローチ
}

\section{A Posterolateral Transmuscular Approach for Ventrally Located Tumors at the Craniovertebral Junction}

$\begin{array}{lllll}\text { 乾 敏 彦*1 } & \text { 村 上昌 宏*1 } & \text { 長 尾 紀 昭*1 } & \text { 宮 㟝晃一*1 } \\ \text { 祖母井 龍*2 } & \text { 松田 } & \text { 康*2 } & \text { 富 永 良子*2 } & \text { 山里 景 祥*2 } \\ \text { 北野昌 彦*2 } & \text { 長谷川 } & \text { 洋*2 } & \text { 富 永 紳 介*2 } & \end{array}$

Toshihiko Inui, M.D., Masahiro Murakami, M.D., Noriaki Nagao, M.D., Kouichi Miyazaki, M.D.,

Ryu Ubagai, M.D., Kou Matsuda, M.D., Yoshiko Tominaga, M.D., Keisyou Yamazato, M.D.,

Masahiko Kitano, M.D., Hiroshi Hasegawa, M.D., Shinsuke Tominaga, M.D.

\begin{abstract}
Introduction : Surgical approachs for ventrally located spinal tumors at the craniovertebral junction (CVJ) remains to be controversial. There are two major concerns. The first is that, the approaches may injure the spinal cord owing to the tension during surgical manipulations. The second concern is that, various problems associated with postoperative spinal instability, malalignment, atrophies of the paraspinal muscles, and axial pain may occur. Here, we present a posterolateral transmuscular (PLTM) approach aimed at reducing these concerns.

Patients : From 2003 to 2012, 7 patients with ventrally located tumors at the CVJ were treated at Tominaga Hospital via the PLTM approach without additional posterior fixation. The patients had the following conditions : C2 neurinomas in 3 patients, C3 neurinomas in 2, and meningiomas in 2. All tumors extended ventrally across the midline. All patients presented with progressively worsening radiculomyelopathy and/or nuchal pain.

Methods : The angle between the plane of the tumor-cord interface (TCl) and the plane parallel to the posterior surface of the vertebral body was determined. The PLTM approach was then classified into two varieties depending on this angle (TCIA). When the TCIA was more than $40^{\circ}$, a medial-PLTM approach was selected. When the TCIA was less than $40^{\circ}$, a lateral-PLTM approach was selected. A linear vertical skin incision was made $2-3 \mathrm{~cm}$ lateral from the dorsal midline in the medial-PLTM approach and 6-8 cm lateral from a dorsal midline in the lateral-PLTM approach. The length of this incision was 1-2 cm greater than the maximum sagittal length of the tumor. The lamina and facets were resected on the ipsilateral side, while preserving $>50 \%$ of the facet. Depending on the vertical location of the tumors, other approaches were selected to avoid splitting and/or retracting muscles. Such approaches include the one via the suboccipital triangle, where the suboccipital muscles were retracted that was performed when the tumor was located at the $\mathrm{C} 0-2$ level. Another approach was via the area between the inferior oblique and multifidus muscles, which was performed when the tumor was located at the C2-3 level. With the availability of these options, tumors can be approached with minimal splitting and/or retracting of the paraspinal muscles and can be removed without or the minimum need for spinal cord retraction.

Results : In all the patients, gross total tumor removal was performed, and the patients' symptoms either disappeared or were markedly alleviated. No postoperative instability was observed in any patients ; no additional spinal fixation was needed, and no postoperative neurological complications, including axial pain, occurred.

Conclusion: The PLTM approach described here is very useful because it is minimally invasive. Tumors at the CVJ can be removed safely and easily under direct observation via the ventral area of the $\mathrm{TCl}$ plane while preserving musculoskeletal integrity.
\end{abstract}

(Received : May 23, 2013 ; accepted : December 19, 2013)

\section{Key words}

posterolateral transmuscular approach, musculoskeletal integrity, tumor-cord interface, ventrally located tumors, craniovertebral junction

*1 富永病院脳神経外科脊椎・脊髄治療センター / $5556-0017$ 大阪市浪速区湊町 1-4-48〔連絡先：乾 敏彦〕

Address reprint requests to : Toshihiko Inui, M.D., Spine Center, Department of Neurosurgery, Tominaga Hospital, 1-4-48 Minatomachi, Naniwa-ku, Osaka-shi, Osaka 556-0017, Japan

*2 富永病院脳神経外科 


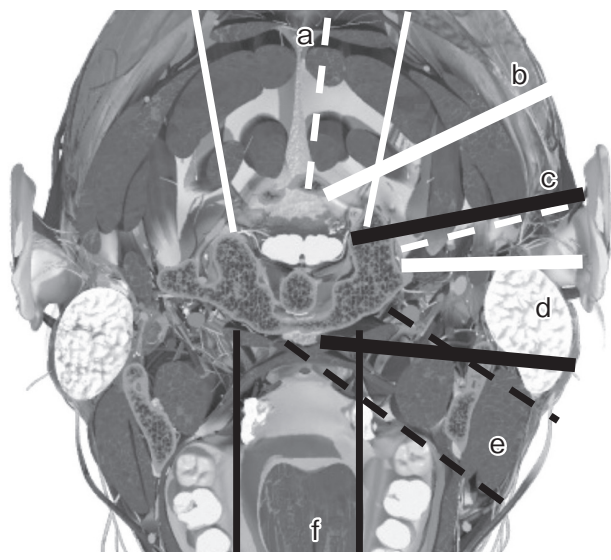

Fig. 1 Various approaches to the CVJ on an anatomical axial image

$\mathbf{a}$ : posterior, $\mathbf{b}$ : posterolateral, $\mathbf{c}$ : lateral and anterolateral (by George et al), d : lateral, extreme lateral, and anterolateral, e : anterolateral (retropharyngeal), f : anterior (transoral).

\section{緒 言}

頭蓋頝椎移行部（craniovertebral junction：CVJ）は後 頭骨の頭蓋底部 $(\mathrm{C} 0)$, 環椎 $(\mathrm{C} 1)$ および軸椎 $(\mathrm{C} 2)$ か らなる。本稿に㧍ける腹側腫瘍の定義は，腹側正中の両 側にまたがる腫瘍とする。

CVJ の脊髄腹側腫瘍に対するアプローチは, 手術操作 による脊髄の圧迫が原因となる神経障害および術後の脊 柱不安定性, 変形, 筋萎縮や軸性疼痛の問題点のために 容易ではない，現在までに前方，側方，後方アプローチ に大別できる各種手術法（Fig. 1）が行われているが, どのアプローチが優れているかは，いまだ議論がありコ ンセンサスは得られていない.われわれは CVJ の腹側腫 瘍に対し，従来型後方（後正中，後外側）アプローチと は異なる片側進入による新しい筋骨格系統合性温存的後 外側経筋間 (PosteroLateral TransMuscular：PLTM) アプ ローチを行い，満足すべき結果を得ている.

PLTM アプローチの手術手技扮よび有用性と問題点を 報告する。

\section{手術手技}

体位は腹臥位，頭部は 3 点固定器で中間位に固定する ことで筋骨格系の解剖学的理解が容易となる。経頭蓋運 動誘発電位, 感覚誘発電位モニター下に手術を行う. 皮 膚切開は, 腫瘍-资髄境界面 (tumor-cord interface：TCI) の延長が皮膚面と交差する線が術野に含まれ，傍脊柱筋 に対し可及的低侵襲な進入経路が得られる部位に，傍脊 柱筋の腫瘍の矢状面最大長に $1 \sim 2 \mathrm{~cm}$ を加えた長さ（最

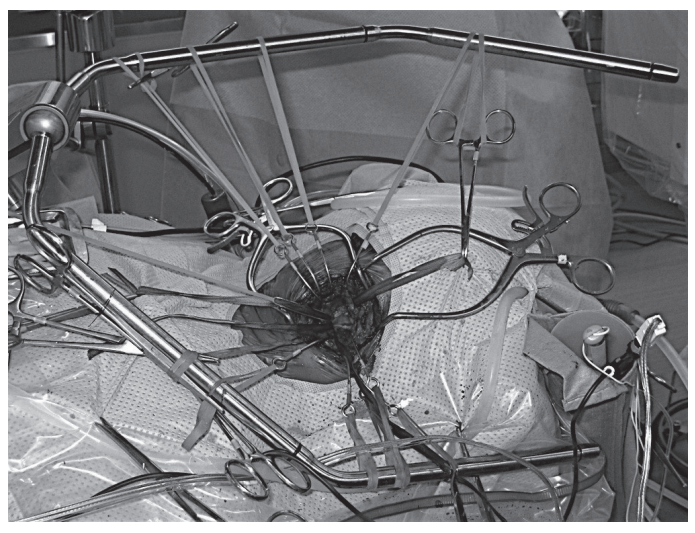

Fig. 2 Case 7

Intraoperative photograph showing muscle retraction using big tissue hooks.

小 4 5 cm） の線状縦切開とする. 傍脊柱筋は，筋の起 始・停止部からの剝離は不要で，各筋層間や個々の筋間 に介在する脂肪層や結合織の剝離を外科用剪刀, 剝離子 や筋鈎を用いておもに鈍的に行う。筋腹を牽引儿剝離部 位に適度な緊張を加えることで, 剝離操作が容易となる。 また必要に応じて外科用剪刀により鋭的剝離を行うが, 最小限に止める。低出力の電気入久の使用は剝離操作を 容易にするが，椎骨動脈（VA）V3 部近傍では不用意な 使用を避ける。この剝離操作により筋の牽引が容易とな るだけでなく，筋膜で覆われた筋線維の走行方向が確認 できる，筋線維の走行方向の把握は，個々の筋の 3 次元 的形態と起始・停止部の理解と合わせ筋の同定を可能と し，解剖学的指標となる棘突起，椎弓，側塊などの骨性 構造物は用手的に触診にて確認できる。術野の拡大が必 要なときにも筋を無理に牽引せず，軽度の力で牽引でき るように勒带・腱を筋付着部近傍まで剥離する。適切な 術野をより小さな皮膚切開で得るために big tissue hook を使用する (Fig. 2)。筋線維間の split を最小限に 留めることができるアプローチ経路を用い，TCI と椎体 後面のなす角度（TCIA）より小さな角度でアプローチ可 能な術野を経筋間に確保する。ややむを得ず TCIA を越え る症例でもできるだけ小さい角度とする。骨切除は必要 に応じ片側椎弓切除を行い, 進入側の環軸椎関節の完全 な温存，椎間関節の 2 分の 1 以上の温存など，可及的に 後方支持成分を温存し，筋骨格系の解剖学的連続性を温 存する。脊髄腹側の対側外側縁まで進展した腫瘍に対し ても，TCI を直視下に脊䯣に無理な牽引・圧迫を加えず 腫瘍摘出を行う.

アプローチ経路の違いにより, medial-PLTM, lateralPLTM アプローチのいずれかを選択する（Fig. 3)．さら に，腫瘍の主座が $\mathrm{C} 0-2$ 高位か $\mathrm{C} 2-3$ 高位かの違いによ 

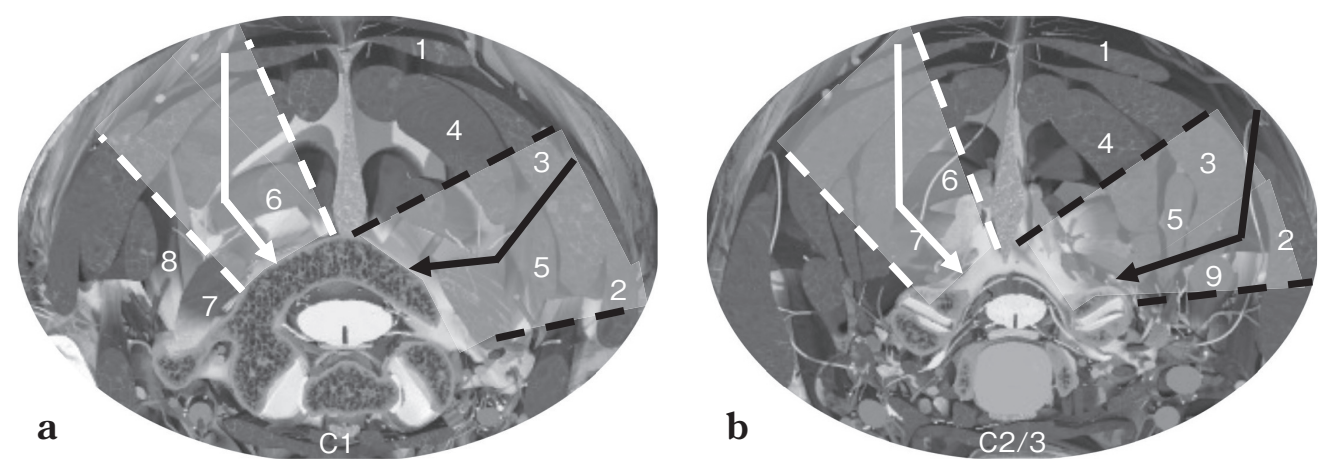

Fig. 3 The medial-PLTM and lateral-PLTM approaches to C0-2 and C2-3 levels on an anatomical axial image The relation of the approach route (medial-PLTM : white arrow ; lateral-PLTM, black arrow) to the obtained operative field (medial-PLTM and lateral-PLTM : white semi-lucent area), a : C0-2 and $\mathbf{b}:$ C2-3 levels, and $1:$ trapezius, $2:$ sternocleidomastoideus, $3:$ splenius capitis, 4 : semispinalis capitis, $5:$ longissimus capitis, $6:$ rectus capitis posterior major, $7:$ inferior oblique, $8:$ superior oblique, $9:$ levator scapulae muscles.

り, 3 層に分けられる後䅡部の筋層のうちの第 2 層まで の筋の展開法が異なる。

\section{Medial-PLTM アプローチ}

皮虐切開は正中より $2 \sim 3 \mathrm{~cm}$ 外側傍正中. 第 1 層: 僧 帽筋は C $0-2$ 腫瘍では内側・尾側に牽引し, C $2-3$ 腫瘍で は splitする.第 2 層：頭板状筋は $\mathrm{C} 0-2$ 腫瘍では外側 · 尾側に毫引し，C2-3 腫瘍では split または外側・尾側に 牽引し, 頭半棘筋は $\mathrm{C} 0-2, \mathrm{C} 2-3$ 腫瘍ともに split する.

\section{Lateral-PLTM アプローチ}

皮膚切開は正中より $6 \sim 8 \mathrm{~cm}$ 外側. 第 1 層: $\mathrm{C} 0-2$, C2-3 腫瘍ともに, 僧帽筋は内側・尾側・背側に拣引し, 胸鎖乳突筋は必要に応じ外側・腹側に牽引する。第 2 層：C0-2 腫瘍では頭板状筋を split，頭半棘筋を内側・ 背側に毫引，頭最長筋を外側・腹側に毫引し頭半棘笳と 頭最長筋の筋間を経由し第 3 層筋群に至る。C2-3 腫瘍 では頭板状筋を頭最長筋，頭半棘筋とともに内側・背側 に牽引，肩甲挙筋を外側・腹側に牽引し頭板状筋と肩甲 挙筋の筋間を経由し第 3 層筋群に至る. 大後頭神経を中 枢へたどり C2 神経根の温存を図り下頭斜筋の C1 唄塊 への停止部を同定する.

第 3 層に到達以降の手術操作は, 得られる operative trajectory に違いがあるが, medial-PLTM と lateralPLTM アプローチ間に基本的な差はなく, $\mathrm{C} 0-2, \mathrm{C} 2-3$ 腫 瘍ともに筋骨格系の解剖学的連続性を温存する.

\section{CO-2 腫瘍}

原則，後頭下三角を経由する。後頭下三角を構成する 筋群は, 起始部, 停止部の䟝離は不要で, 上頭斜筋は頭 側 - 外側 ·腹側に, 下頭斜筋は尾側 ·外側 ·腹側に, 大 後頭直筋は頭側・内側・背側に必要に応じて牽引する. 腫瘍の進展が斜台下 3 分の 1 まで及ぶときは, 大後頭直 筋は，筋の発達程度により，後頭骨の筋停止部の部分的
剝離や尾側・外側・腹側への牽引を行う。

\section{C2-3 腫瘍}

下頭斜筋と多裂筋の間の筋の起始・停止部がなく筋性 要素がそしいスペースを経由する.さらに必要に応じて， 下頭斜筋を頭側 · 内側 · 背側に, 多裂筋を尾側 · 内側 · 背側に牽引することで広い術野が得られる.

\section{対 象 (Table 1)}

2003 2012 年に CVJ の春髄腹側腫瘍に対し当院で PLTM アプローチを行った進行性に増悪する春髄症，神 経根症や項澒部痛を伴う 9 例（C2 神経鞘腫：3 例， C3 神経鞘腫 $: 2$ 例, 再発性脊索腫: 2 例, 髄膜腫: 2 例）の うち，腫瘍によるC1-2 の広範な骨破壊のため後方 instrumentationの併用を要した再発性脊索腫の 2 例を 除いた 7 例を対象とした. Medial-PLTM アプローチは 5 例，lateral-PLTM アプローチは 2 例で選択された。全 例で腫瘍は脊髄腹側正中を越え対側まで進展していた。

\section{代表症例}

【Case 6】：65 歳，女性（Fig. 4).

7 カ月前より, 次第に増悪する両上肢しびれがあり， 筋力低下も出現し紹介入院となる。入院時，両上肢の筋 力低下 $(\mathrm{MMT}: 3 \sim 4 / 5)$, 四肢の深部腱反射克進, 病的 反射の出現を認めた。術前 MRI では $\mathrm{C} 2$ 高位硬膜腹側に 付着を有し，均一に造影される硬膜内䯣外腫瘍を認め， 脊髄は高度に圧排・扁平化されており，右肩甲挙筋の有 意な筋萎縮を認めた。手術は lateral-PLTM アプローチ で行い，腫瘍内減圧後の TCIA が縮小しないように歯状 勒帯の切断・星引を行い, 脊髄を圧迫せずに TCI を直視 
Table 1 Summary of patients

\begin{tabular}{|c|c|c|c|c|c|c|c|c|c|c|}
\hline \multirow{2}{*}{ Case } & \multirow{2}{*}{ Age/Sex } & \multirow{2}{*}{ Diagnosis } & \multirow{2}{*}{ Extent } & \multirow{2}{*}{$\begin{array}{c}\text { TCIA } \\
\left({ }^{\circ}\right)\end{array}$} & \multirow{2}{*}{$\mathrm{TR}$} & \multirow{2}{*}{ PLTM } & \multirow{2}{*}{$\begin{array}{l}\text { FRR } \\
(\%)\end{array}$} & \multirow{2}{*}{$\begin{array}{l}\text { Sig. } \\
\text { MA }\end{array}$} & \multicolumn{2}{|c|}{ FFU } \\
\hline & & & & & & & & & Inst & (mo) \\
\hline 1 & $70 / \mathrm{F}$ & $\mathrm{C} 2 \mathrm{sch}$ & $\mathrm{C} 1-2$ & 78 & $\mathrm{G}$ & Medial & 0 & SplCap & None & 70 \\
\hline 2 & $51 / \mathrm{F}$ & $\mathrm{C} 2 \mathrm{sch}$ & $\mathrm{C} 1-2$ & 55 & G & Medial & 0 & None & None & 18 \\
\hline 3 & $41 / \mathrm{M}$ & $\mathrm{C} 2 \mathrm{sch}$ & $\mathrm{C} 1-2$ & 48 & G & Medial & 0 & None & None & 3 \\
\hline 4 & $26 / \mathrm{F}$ & C3 sch & $\mathrm{C} 2-3$ & 31 & G & Medial & 40 & InfObl & None & 114 \\
\hline 5 & $42 / \mathrm{M}$ & $\mathrm{C} 3 \mathrm{sch}$ & $\mathrm{C} 2-3$ & 52 & G & Medial & 10 & NA & None & 0.5 \\
\hline 6 & $65 / \mathrm{F}$ & menin & $\mathrm{C} 2-4$ & 32 & $\mathrm{G}$ & Lateral & 25 & None & None & 18 \\
\hline 7 & $40 / \mathrm{M}$ & menin & $\mathrm{C} 0-2$ & 38 & G & Lateral & 0 & None & None & 5 \\
\hline
\end{tabular}

Sch : schwannoma, Menin : meningioma, TCIA : the angle between a tumor-cord interface plane and the posterior surface plane of the vertebral body, TR : tumor removal, G : gross total removal, FRR : facet resection rate, Sig : significant $(\geq 30 \%)$, MA : muscle atrophy, SplCap : splenius capitis muscle, InfObl : inferior oblique muscle, NA : not applicable, FFU : final follow-up period, Inst : instability

下に腫瘍の内減圧を行い，腫瘍付着部の硬膜内層を含め て腫瘍を全摘出した．腫瘍との癒着が強固であった C4 前根糸の一部が損傷された。病理診断は血管腫性髄膜腫 (MIB-1:4\%) であった。術後症状は消失し，筋力は速 やかに改善し，新たな脱落症状はなかった。

【Case 7】：40 歳, 男性（Fig. 5).

3 力月前より, 頚部痛が出現・持続し鍼治療を行って いた。両上肢，左下肢のしびれ，両上肢の脱力を自覚， 数日間で増悪し紹介入院となる。入院時, 両上下肢の温 痛覚低下, 両上肢の筋力低下 $(\mathrm{MMT}: 4+/ 5)$, 痓性歩行 を認め, 四肢の深部腱反射は㐫進し, 病的反射の出現も 認めた. 術前 MRI では C $0-1$ 高位硬膜腹側から右外側に 付着を有し，均一に造影される硬膜内髄外腫瘍を認め， 春髄は高度に圧排・扁平化されていた。左大後頭直筋は 広範に T2 高信号, 不均一に造影され腫大しており, 感 染による変化であることが術後に判明した。手術は lateral-PLTM アプローチで行い, 腫大した大後頭直筋を尾 側・外側・腹側に牽引したスペースから腫瘍を摘出し た。 大後頭直筋の剝離操作時に, 炎症のため癒着が強く 右 V3 部で椎骨動脈（VA）損傷をきたした。歯状勒帯の 切断を加え，脊髄を圧迫せずに TCI を直視下に腫瘍の内 減圧と一部軟膜下に浸潤していた腫瘍の剝離を行った。 副神経を温存し，腫瘍付着部の硬膜内層を含めて腫瘍を 全摘出した。病理診断は非定型髄膜腫（MIB-1:23\%） であった。術後症状は著明に改善し，脳梗塞や新たな脱 落症状も認めなかった。

\section{結＼cjkstart果（Table 1)}

術後症状は消失または著明に改善し，神経学的合併症 や軸性疼痛は認めなかった。全例で肉眼的全摘出がなさ れた。椎弓切除は進入側片側部分〜全切除され，椎間関
節切除は片側部分 2 分の 1 以下の切除であり, 春椎固 定の追加は不要で, 筋・骨格系の解剖学的・機能的温存 がなされた。最終観察時の椎間の不安定性は認めず，無 症候性の若干の手術高位局所側弯を認めた Case 4 を除 き脊柱 alignment の悪化も認めず, 腫瘍再発も認めない. Case 7 で進入側の VA 損傷をきたしたが，幸い対側 VA からの血流により脳梗塞はきたさず，神経学的合併症は 認めなかった。

術後 2 週間で退院後に通院をしなかった Case 5 を除 く, 術後 3 力月以上の経過観察が可能であった 6 例で, MRI による後頭下筋群，傍脊柱筋損傷の検討を行った

(Table 1，Fig. 6)．30\%以上の明らかな筋萎縮を認めた のは 2 例（Case 1，4）であった。

\section{考 察}

\section{CVJ の機能解剖学的特性}

CVJ は C3 以下の脊椎とは全く構造が異なり, $\mathrm{C} 0-1$ 関 節と $\mathrm{C} 1-2$ 関節をもつ $\mathrm{C} 0-1-2$ が単一のモーションユ ニットとして働き, 複雑で 3 次元的な全脊椎で最大の可 動性を有する部位である。C1-2 関節は両凸の形状であ り, 各種勒带構造が脊椎安定化に重要な働きをしている が，本来不安定性をきたしやすい部位である ${ }^{1)}$ ，そのた め不安定性の予防には，C0-1，C1-2 関節，各種勒带構 造の温存が重要となる。さらに棘突起に直接的に停止部 をもつ頚部深層伸筋群（䅡半棘筋，多裂筋）は，レバー アーム機能を有し䅡椎の運動機能と安定化作用に重要な 役割を果たしている ${ }^{2,3)}$ 。また $\mathrm{C} 2$ 棘突起に停止部をもつ 䅡半棘筋は, 頚椎の生理的前弯の維持に最も重要とされ $る^{3 \sim 5}$. C2 棘突起に起始・停止部をもつ後頭下筋群（大 後頭直筋，下頭斜筋)，頚部深層伸筋群は，CVJ の安定 性, 運動機能, alignment の維持に重要かつ不可欠な役割 

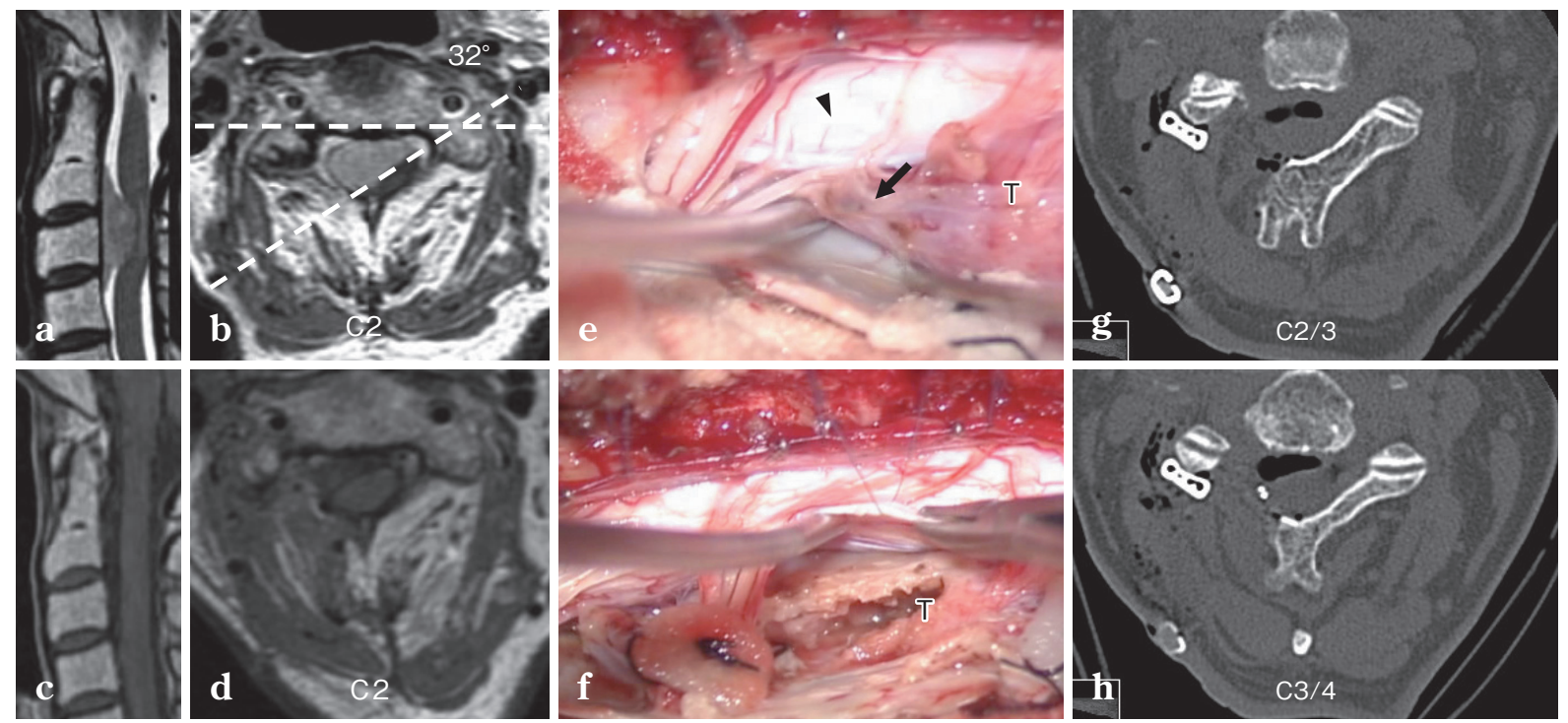

Fig. 4 Case 6

a : A sagittal T2-weighted MRI scan of a ventrally located meningioma at the $\mathrm{C} 2-4$ level.

b : An axial T1-weighted gadolinium-enhanced scan of a meningioma extending to the contralateral lateral border. The angle of the intersection of two broken lines showing a TCIA of $32^{\circ}$.

c, d : A postoperative T1-weighted enhanced sagittal scan (c) and an axial scan (d) showing gross total removal of the tumor.

e, f : Intraoperative photographs showing the cervical cord (e : arrow head) compressed dorsolaterally by a meningioma $(\mathrm{T})$, for which the inner layer of the dural attachment was removed (e) and the dentate ligament was retracted to preserve the TCIA before tumor removal (f). The ventral surface of the cervical cord and the contralateral lateral border of the ventral dura mater can be seen (f).

$\mathbf{g}, \mathbf{h}$ : A postoperative CT scan showing preserved facets of the $\mathrm{C} 2 / 3(\mathbf{g}), \mathrm{C} 3 / 4(\mathbf{h})$ and a suction tube on the right facet.
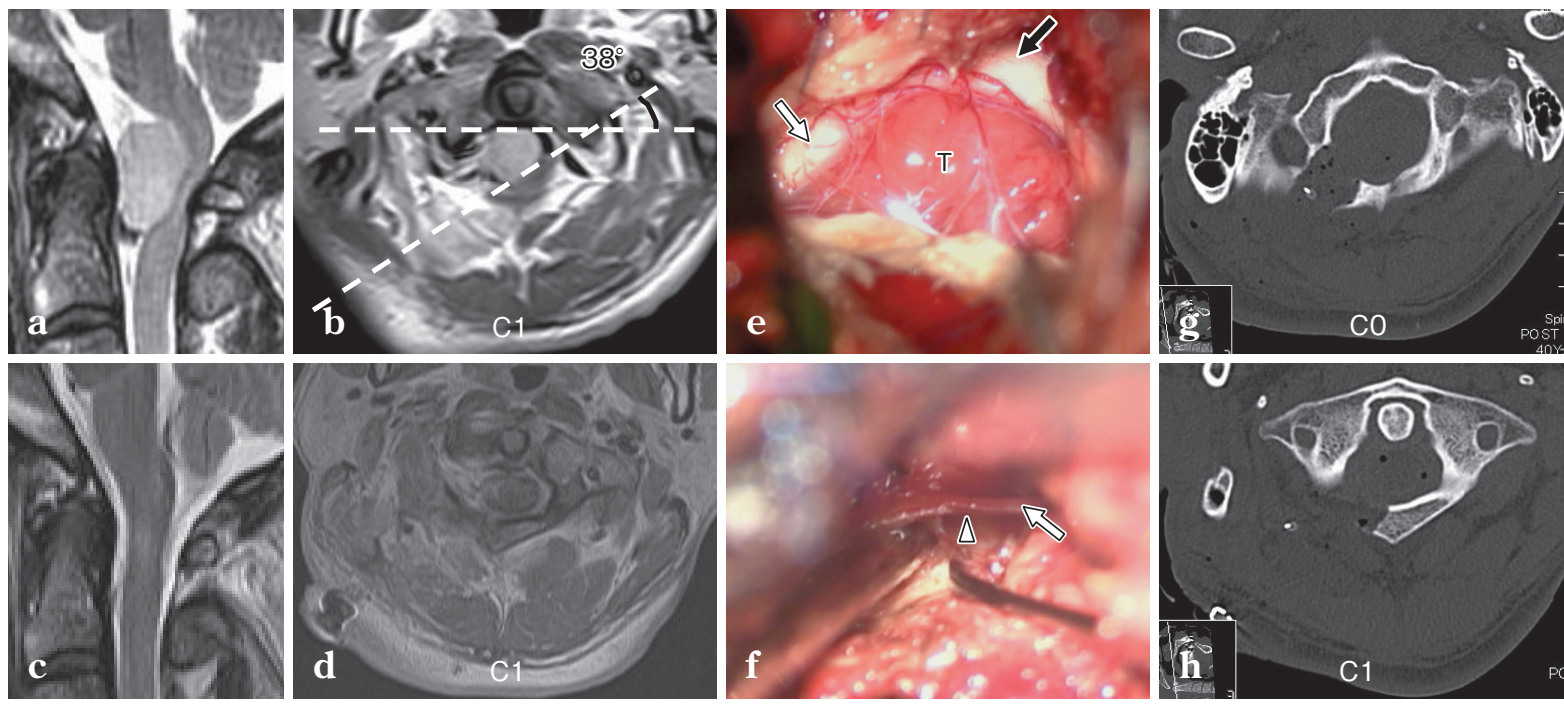

Fig. 5 Case 7

a : T2-weighted MRI scan of a ventrally located meningioma at the craniovertebral junction.

b : T1-weighted enhanced scan showing a meningioma extending to the contralateral lateral border. The angle of the intersection of two broken lines showing a TCIA of $38^{\circ}$.

c , d : A postoperative T2-weighted scan (c) and T1-weighted enhanced scan (d) showing gross total removal of the tumor.

e, f : An intraoperative photograph showing the upper cervical cord (e : white arrow) and the lower medulla (e : black arrow) compressed dorsolaterally by the meningioma $(\mathrm{T})$, for which the inner layer of the dural attachment was removed $(\mathbf{f})$ and the accessory nerve (f : arrow) and the contralateral lateral border of the ventral dura matter (arrow head) were preserved.

$\mathbf{g}, \mathbf{h}$ : A postoperative CT scan demonstrating suboccipital craniectomy $(\mathbf{g})$ and partial removal of the C1 posterior arch $(\mathbf{h})$. 
を果たしている ${ }^{6)}$. C2 棘突起からの筋起始部や停止部の 剝離は, 剝離した筋肉の明らかな萎縮をきたし $\left.{ }^{4,6} 8\right)$, 術 後の脊椎不安定性の出現, alignment の悪化, 残存する軸 性疼痛, 肩こり, 䅡椎の可動域制限の原因となる ${ }^{6,7,9,10)}$.

CVJ の脊髄腹側腫瘍に対し, 現在までに前方, 側方, 後方アプローチに大別できる各種手術法が行われている

(Fig. 1)。どのアプローチが優れているかは，いまだ議 論のあるところでコンセンサスは得られていない。腫瘍 の局在（進展部位·方向, 大きさ, 形状, 硬膜内 - 外, くも膜面の破綻の有無, 軟膜下への進展 - 浸潤の有無), 性状 (固さ, 組織型), 術者の慣れ・好みなどによりアプ ローチが選択されているのが現状である.

\section{PLTM と各種アプローチの比較検討}

\section{1. 前方アプローチ}

Transoral appoach ${ }^{11 \sim 15)}$ に代表され，脊髄を圧迫するこ となく病変に直接到達できることは PLTM アプローチ と同等またはより優れている。一般的適応である硬膜外 病変13,14) は, 術野が深く狭いために視野が脊柱管中央に 限局される ${ }^{15,16)}$ が, PLTM アプローチより適している.骨 性構造物・各種勒带・椎間板の広範な切除により通常脊 椎固定の追加を要するが, PLTM アプローチでは原則不 要である.

\section{2. 側方アプローチ}

前方アプローチの一種である anterolateral retropharyngeal approach ${ }^{17,18)}$ と同様の術野を確保でき, 1980 年 に Shucart ら ${ }^{19)} に よ り$ 報告された lateral approach，1990 年にSen, Sekhar ${ }^{16,20)}$ により報告された exterme lateral approach に代表される. George ら ${ }^{21)}$ は 1995 年に posterolateral approach に対して前方からアプローチするとい う意味での側方アプローチである anterolateral approach を報告している，いずれの側方アプローチも， LateralPLTM アプローチと同様に真の側方からの視野が得ら れ, C $0-1, \mathrm{C} 1-2$ 関節や勒帯が損傷されなければ脊椎固 定の追加は不要となる ${ }^{16,19,20)}$. 硬膜内病変における術後 の脳脊髄液漏, 髄膜炎も硬膜閉鎖が容易で, 回避可能と なる. Lateral-PLTM アプローチとの違いは, 得られる術 野は硬膜内スペースは側方アプローチでより狭く, 硬膜 外スペースは側方アプローチがより広い ${ }^{16,19,20)}$. さらに 側方アプローチでは, 後頭骨, C1 側塊における筋骨格系 や肩甲挙筋の解剖学的連続性が絶たれることも違いであ る. 骨病変や硬膜外の腹側, 外側病変のアプローチでは, 病変部位の筋骨格系の解剖学的連続性が絶たれることは やむを得ないため側方アプローチが有用であり, 硬膜内 病変ではその連続性を絶つ必要がないため lateralPLTM アプローチが有用である. George $ら^{21)}$ antero- lateral approach は骨病変や硬膜外の腹側, 外側病変のア プローチに有用で, posterolateral approach は通常の後正 中アプローチの側方展開を大きくし, 腫瘍の摘出腔を利 用した手術が可能で硬膜内病変に有用であるとしてい る.

\section{3. 後方アプローチ}

後正中アプローチと後外側アプローチが行われるが, 両者の違いの定義は曖昧である。一般的には，後正中ア プローチの術野の外側展開を拡大し, より外側からの術 野を得やすいアプローチが後外側アプローチ（従来型後 外側アプローチ）に分類される ${ }^{21,22)}$. 後外側アプローチ では，後頭顆の部分削除が術後の不安定性をきたすこと なく術野を拡大するのに有用であり ${ }^{23)}$ ，骨削除範囲によ り tarnscondylar approach, transcondylar fossa approach, far lateral approach など多くの亜型に分類される.

後正中アプローチは, 傍脊柱筋, 後頭下筋群が術野の 広範な側方展開の妨げとなり，腫瘍摘出腔を利用できな い場合は脊髄に無理な圧迫を加えずに安全に得られる硬 膜内髄外の範囲は脊髄の腹外側 4 分の 1 で, 歯状勒带を 切除して脊髄をゆっくり回転させても腹側中央までであ る22. CVJ はくも膜下腔がほかの脊椎レベルに比べて広 く, 必要に応じて $\mathrm{C} 1,2$ 神経根を切除しても重篤な神経 障害が出現せず，硬膜内髄外の腹側に位置する腫瘍は左 右のどちらかに偏在し，腹外側に進展することが多い. また，延髄・上位䅡髄が腫瘍によりすでに圧排されてい る.そのため, 歯状勒带を切断し脊髄をゆっくりと回転 させることで, 腫瘍内減圧後の腫瘍摘出腔を利用し多く の硬膜内髄外の腫瘍摘出に適応することができ，良好な 成績が報告されている ${ }^{21,22,24,25)}$. しかし正中腹側に限局す る腫瘍など腫瘍摘出腔を利用できない場合は, 術後脱落 症状なしに全摘出することは今なお困難である ${ }^{19)}$.

後外側アプローチは，後正中アプローチより外側から の術野を容易に得ることのできる有用なアプローチであ り, PLTM アプローチと同様に脊髄腹側正中を越え対側 まで腫瘍が進展する硬膜内髄外の例で用いられることが 多い. 1991 年に Yasargil ら ${ }^{26)}$ は, operative trajectory をよ り外側から得るために片側の傍正中の皮膚線状縦切開で 片側の筋群を後正中より剝離することの有用性を報告し ている．TCI を直視下に腫瘍摘出を行うためには，従来 型後外側アプローチはもちろんのこと, Yasargil らの方 法でも medial-PLTM と同様の operative trajectory を得 られるが, 術野の頭尾側方向への拡大も必要とする大き な側方展開を要する。アプローチ側の後頭下筋群は起 始・停止部を $\mathrm{C} 2$ 棘突起や後頭骨より剝離し, 頚半棘筋 起始部の $\mathrm{C} 2$ 棘突起よりの剝離, ほかの傍脊柱筋の起 

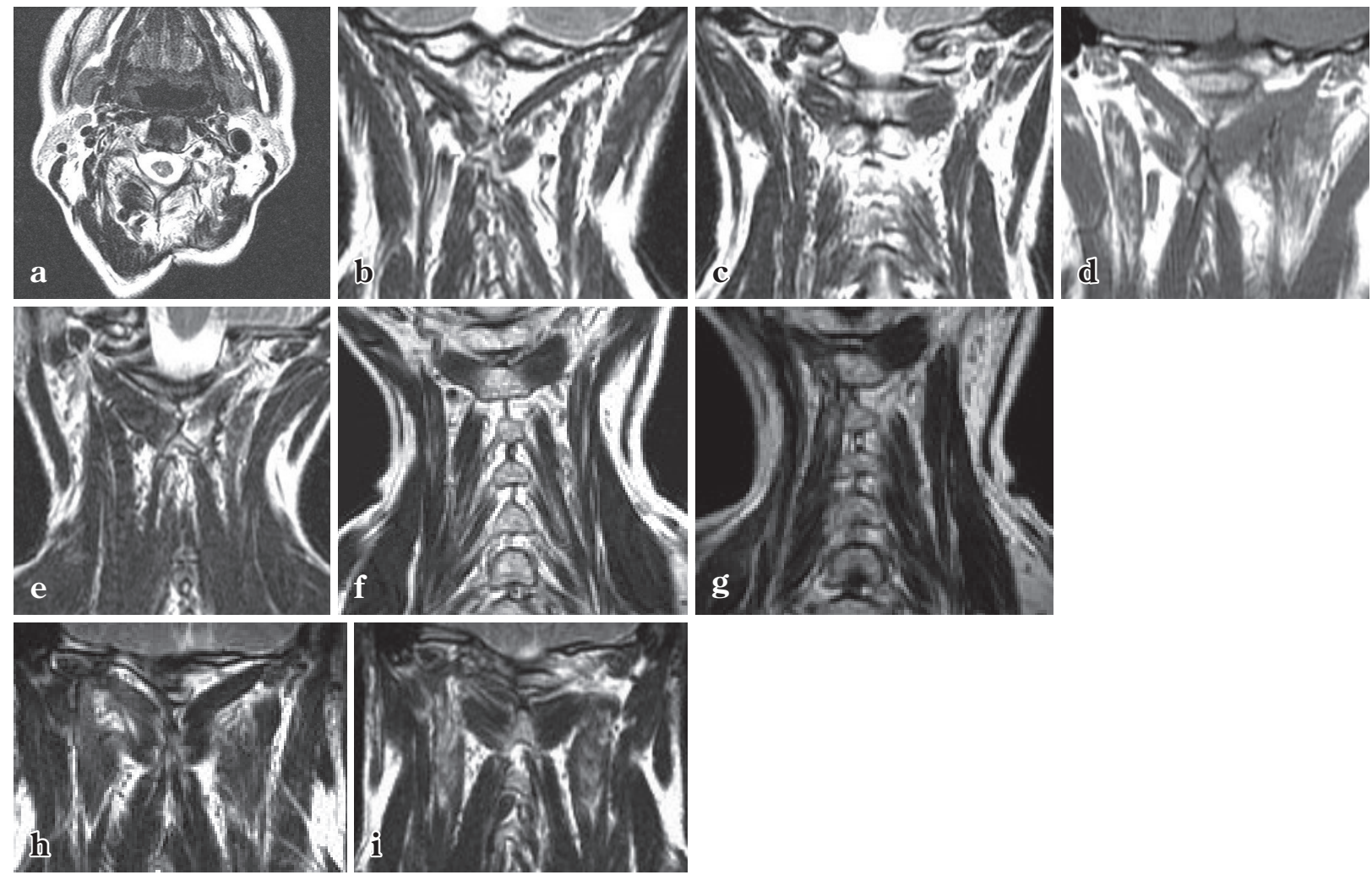

Fig. 6 Assessment of muscle damage on a postoperative T2-weighted MRI scan

a : Case 1; An axial scan obtained 70 months later showing the significant muscle atrophy of left splenius capitis and inferior oblique.

$\mathbf{b} \sim \mathbf{d}$ : Sagittal scans obtained 18 months later (b, c : Case 2) and a sagittal scan obtained 3 months later (d : Case 3 ) showing no significant muscle atrophy and no hyper intensity of any muscles.

e : Case 4 ; A sagittal scan obtained 114 months later showing the significant muscle atrophy of inferior oblique.

f , g : Case 6 ; A sagittal scan obtained before the operation $(\mathbf{f})$ and a sagittal scan obtained 18 months later $(\mathbf{g})$ showing similar significant muscle atrophy of the right levator scapulae muscle.

h, i : Case 7 ; A sagittal scan obtained 5 months later showing no significant muscle atrophy and slightly partial hyper intensity of the right rectus capitis posterior major muscle.

始・停止部の棘突起や椎弓よりの広範な剝離も余儀なく される。これらの点および lateral-PLTM アプローチで 得られるほぼ真横からの operative trajectory の獲得が困 難なことが PLTM アプローチと異なる。より小さな皮膚 切開で十分な術野の側方展開が可能であることも, PLTM アプローチの利点であり, big tissue hook の使用 (Fig. 2) が有用となる.

CVJ 脊髄腹側病変に対する理想的アプローチは，脊䯣 に無理な圧迫を加えずに腫瘍および TCI を直視下に摘 出することができ，固定術の追加を要せず，筋骨格系の 解剖学的連続性と機能的温存がなされるアプローチであ る。われわれが涉猟し得た範囲では，これらすべての条 件を満たすアプローチの報告例はない. PLTM アプロー チは CVJ の機能解剖学的特性を踏まえた理想的アプ ローチを目指したアプローチである。進入経路に関与す る筋群の最大限の解剖学的機能的温存を図るためには, その起始・停止部・神経支配を考慮した最適経路を選択
する必要がある. TCIA により異なり, 40 度以上は medial-PLTM アプローチ，40 度未満は lateral-PLTM アプ ローチの選択が最適経路となる（Fig. 3).

TCIA が 40 度未満でも medial-PLTM アプローチを 行った症例は 1 例であった (Table 1). Case 4 は schwannoma であり春髄腹側との癒着はなく, 歯状勒带を切離 し慎重に脊髄を回転させることで TCI を直視下に容易 に腫瘍摘出が可能であった. Schwannomaのような脊髄 との癒着のない腫瘍は TCIA が 40 度未満でも medialPLTM アプローチで安全な腫瘍摘出が可能である.

Lateral-PLTM アプローチは, 髄膜腫の 2 例ともに選 択されており, 腫瘍の脊䯣腹側面からの繊細な剝離操作 が必要な腫瘍に適している。悪性髄膜腫は pial invasion をきたすことが多く，psammomatous meningioma が pial invasion をきたす傾向もよく知られている ${ }^{27)}$.

本シリーズでは認めなかったが，TCIA が 0 度の症例 でも硬膜内腫瘍では，大半の症例で歯状勒帯の切離によ 
る脊髄の回転操作を加えることで, 神経障害をきたさな い最小限の脊髄の圧迫で腫瘍摘出が可能である.

後頭下筋群, 傍脊柱筋損傷の検討（Table 1) を行った 6 例 (Fig. 6) のうち, PLTM アプローチの初期の症例で 手技の不慣れによる $30 \%$ 以上の有意な筋萎縮をきたし た Case 1 (頭板状筋, 下頭斜筋), Case 4 (下頭斜筋) の 2 例を除き，以後の手技の安定した Case $2,3 ， 6,7$ は有意な術後の筋萎縮の出現・増悪は認めなかった。 Case 6 は無症候性ではあるが肩甲挙筋の著しい筋萎縮 を術前から認め, 肩甲挙筋の支配神経 $(\mathrm{C} 3 ， 4)$ である C 3， 4 前根糸の腫瘍の圧迫による損傷が原因と考える. 症例数が少なく, 経過観察期間も短い症例も含まれるが, 適切な手技で行われた PLTM アプローチによる筋骨格 系の温存は, 解剖学的連続性はもち万ん, 機能的にも最 大限の温存が可能であることを示唆している.

\section{PLTM アプローチの有用性と問題点}

\section{1. 有用性}

(1) C $0-1, C 1-2$ は神経根の腹側に関節が位置し, 頝椎 高位は椎間関節が薄く椎弓根も短いため, 大半の症例で 椎弓根を温存し椎間関節の切除範囲を 2 分の 1 以下に 留めた腫瘍摘出が可能で固定術の追加は不要.

(2)TCI 腹側より腫瘍を直視下に安全に摘出可能.

(3)最小限の筋 split および筋の牽引にて経筋間にアプ ローチが可能で，CVJ に関与する筋骨格系や肩甲挙筋， 胸鎖乳突筋の解剖学的連続性が得られ, 最大限の機能的 温存が期待できる.

(4)温存が重要とされる副神経も損傷の危険性はない.

(5)VAの必要に応じた早期確保, 転移, 血行再建が可 能.

６硬膜内髄外腫瘍に有用であり硬膜の縫合閉鎖は容易 で, 前方アプローチで問題となる術後䯣液漏や感染症の 回避が可能.

\section{2. 問題点}

(1)脊髄の腹側，外側の骨性要素を広範に浸食し，傍脊 柱軟部組織まで進展する腫瘍は適応がない.

(2)脊髄腹側正中部に限局するものや腫瘍が完全に脊髄 で覆われる硬膜外腫瘍では春髄の回転操作ができないた め, 術野が狭く対象症例は限られる。

(3)髄内腫瘍は偏心性で脊髄表面に腫瘍が進展している 一部の症例に適応が限られる。

(4)同一術野での後方 instrumentation を併用した固定 術の追加は, medial-PLTM アプローチは片側のみ可能 で, lateral-PLTM アプローチでは不可能であり, 別に後 正中切開を加えると可能となる。その際，必須ではない が通常の両側性後方除圧術を先行させた後にPLTM ア
プローチを行うことも有用.

(5)C2 をまたぎ頭尾側に進展する髄膜腫摘出のために は，下頭斜筋の起始・停止部を剝離せず，周辺組織から 遊離させ必要に応じて頭側または尾側への毫引を要す る.

(6)VA 損傷の可能性：優位側に扔けるVA 損傷は, 重 大な神経障害を生じることがあり，ときとして致命的に もなり得るため回避することがきわめて重要となる．特 にV3 部は解剖学的走行に個人差が大きく, 症例によっ ては $\mathrm{C} 1$ 後弓より大きく後方, 尾側に偏位して走行する こともあり，術前に MRI, 3D-MRA または 3D-CT アン ギオにより VA の血管径の左右差や走行, 後下小脳動脈 の分岐部位を正確に把握しておく必要がある。V3 部確 保, 硬膜外静脈叢の処理は, medial-PLTM アプローチで は触診にて $\mathrm{C} 1$ 後弓正中付近・側塊, C2 棘突起を捉え, 後頭下三角の筋腹に覆われていない部位を利用して下頭 斜筋を尾側 · 外側 - 腹側に, 大後頭直筋は頭側 ·内側 · 背側に剝離子を用いて鈍的に剝離・率引する。次いで, 後弓正中部から外側に向かって後弓上縁より数 $\mathrm{mm}$ 尾 側で尖刃刀を用い骨膜を切開して骨膜下に頭側へ得離 し, 硬膜外静脈叢を凝固・縮小させながら後正中から外 側へと剝離操作を進めることで安全に行える． LateralPLTM アプローチでも，椎体後面に対する operative trajectory の角度を可及的に大きくとることで同様の操 作により安全に行える．大後頭直筋の発達が良好で後頭 下三角が筋腹で完全に覆われている症例では，大後頭直 筋と下頭斜筋の剝離操作は, 直下にV3 が走行している 可能性があるため，まず下頭斜筋を剝離子による鈍的剝 離を行い, C1 椎骨動脈溝近傍で捉えた後弓下縁に尖刃刀 またはマイクロ剪刀を用いて骨膜を切開し, 骨膜下に頭 側に得離し正中に向かい剝離を進め，以後先述と同様の 操作となる。この際の V3 近位部での VA 確保は若干の 手技の習熟を要する，剝離操作中に適宜，触診や超音波 ドップラーを用いて VA の位置を確認することも有用で ある。

\section{結 語}

頭蓋澒椎移行部の脊髄腹側腫瘍に対する PLTM アプ ローチは, 適応症例も多く, 腫瘍摘出が TCI を直視下に 安全かつ容易に行え, 筋骨格系の解剖学的機能的温存が 図れ, 固定術の追加不要である有用なアプローチである. 今後の症例の蓄積とさらなる科学的検証を要するが, PLTM アプローチは理想的アプローチとなり得ることが 期待できる. 
この論文の要旨の一部は, 第 27 回日本春髄外科学会で発 表されたものである.

利益相反開示：なし

\section{文 献}

1) Zhang $\mathrm{H}$, Bai $\mathrm{J}$ : Development and validation of a finite element model of the occipito-atlantoaxial complex under physiologic loads. Spine $32: 968-974,2007$

2) Nolan JP, Sherk HH: Biomechanical evaluation of the extensor musculature of the cervical spine. Spine $13: 9-11$, 1988

3) Vasavada AN, Li S, Delp S: Influence of muscle morphometry and moment arms on the moment-generating capacity of human neck muscles. Spine $23: 412-422,1998$

4) Iizuka $H$, Nakajima $T$, Iizuka $Y$, et al : Cervical malalignment after laminoplasty : relationship to deep extensor musculature of the cervical spine and neurological outcome. J Neurosurg Spine $7: 610-614,2007$

5) Iizuka $H$, Shimizu $T$, Tateno $K$, et al : Extensor musculature of the cervical spine after laminoplasty: morphologic evaluation by coronal view of the magnetic resonance image. Spine $\mathbf{2 6}$ : 2220-2226, 2001

6) Shiraishi T, Kato M, Yato $Y$, et al : New techniques for exposure of posterior cervical spine through intermuscular planes and their surgical application. Spine 37 : E286-296, 2012

7) Kim P, Murata H, Kurokawa R, et al : Myoarchitectonic spinolaminoplasty: efficacy in reconstituting the cervical musculature and preserving biomechanical function. J Neurosurg Spine $7: 293-304,2007$

8) Shiraishi T, Yato Y, Yoshida H, et al : New double-door laminoplasty procedures to preserve the muscular attachments to the spinous processes including the axis. Eur J Orthop Surg 12 : 175-180, 2002

9) Sakaura H, Hosono N, Mukai Y, et al : Preservation of muscles attached to the $\mathrm{C} 2$ and $\mathrm{C} 7$ spinous processes rather than subaxial deep extensors reduces adverse effects after cervical laminoplasty. Spine 35 : E782-786, 2010

10) Hosono N, Yonenobu K, Ono K : Neck and shoulder pain after laminoplasty. A noticeable complication. Spine 21:19691973, 1993

11) Kanavel $\mathrm{AB}:$ Bullet located between the atlas and the base of the skull: Technique for removal through the mouth. Surg Clin $1: 361-366,1919$

12) Crockard HA, Bradford R : Transoral transclival removal of a schwannoma anterior to the craniocervical junction. J Neurosurg 62:293-295, 1985
13) Miller E, Crockard HA : Transoral transclival removal of anteriorly placed meningiomas at the foramen magnum. Neurosurgery 20 : 966-968, 1987

14) Liu JK, Couldwell WT, Apfelbaum RI : Transoral approach and extended modifications for lesions of the ventral foramen magnum and craniovertebral junction. Skull Base $18: 151-166$, 2008

15）高安正和, 安田宗義, 上甲眞宏, 他 : 歯突起近傍部病変に対 する低侵襲経口手術の工夫と有用性. 脊䯣外科 $20 ： 149-$ 156, 2006

16) Sen CN, Sekhar LN : An extreme lateral approach intradural lesions of the cervical spine and foramen magnum. Neurosurgery 27 : 197-204, 1990

17) Henry AK : Exposure of cervical structures by sternomastoid eversion. in Henry AK (ed) : Extensile Exposure. ( $2^{\text {nd }}$ edition), Edinburg, E \& S Livingston, 1957, pp53-80

18) Whitesides TE Jr, Kelly RP : Lateral approach to the upper cervical spine for anterior fusion. South Med J 59 : 879-883, 1966

19) Shucart WA, Kleriga E : Lateral approach to the upper cervical spine. Neurosurgery $\quad 6: 278-281,1980$

20) Sen CN, Sekhar LN : Surgical management of anteriorly placed lesions at the craniocervical junction : an alternative approach. Acta Neurochir (Wien) 108:70-77, 1991

21) George B, Lot G : Anterolateral and posterolateral approaches to the foramen magnum. Skull Base Surg $5:$ 9-19, 1995

22) Martin NA, Khanna RK, Batzdorf U : Posterolateral cervical or thoracic approach with spinal cord rotation for vascular malformations or tumors of the ventrolateral spinal cord. J Neurosurg $83: 254-261,1995$

23) Ohata K, Baba M : Transcondylar approach. in Hakuba A (ed) : Surgical Anatomy of the Skull Base. Tokyo, Miwa Shoten, 1996, pp141-173

24) Yasuoka S, Okazaki H, Daube JR, et al : Foramen magnum tumors: Analysis of 57 cases of benign extramedullary tumors. J Neurosurg $49: 828-838,1978$

25) Angevine PD, Kellner C, Haque RM, et al : Surgical management of ventral intradural spinal lesions. J Neurosurg Spine $15: 28-37,2011$

26) Yasargil MG, Tranmer BI, Adamson TE, et al : Unilateral partial hemilaminectomy for the removal of extra- and intra medullary tumors and AVMs. Adv Tech Stand Neurosurg 18 : 113-132, 1991

27) Schaller B : Spinal meningioma : relationship between histological subtypes and surgical outcome. J Neurooncol $75: 157-$ 161, 2005 